\title{
RWD Domain-Containing Protein 3
}

National Cancer Institute

\section{Source}

National Cancer Institute. RWD Domain-Containing Protein 3. NCI Thesaurus. Code C105966.

RWD domain-containing protein 3 (267 aa, $31 \mathrm{kDa}$ ) is encoded by the human RWDD3 gene. This protein plays a role in the sumoylation of proteins. 